\title{
E-Court in resolving civil cases - Foreign experiences and recommendations for Vietnam
}

\author{
Nguyen Thi Hong Nhung ${ }^{*}$, Huynh Thi Nam Hai, Luu Minh Sang
}

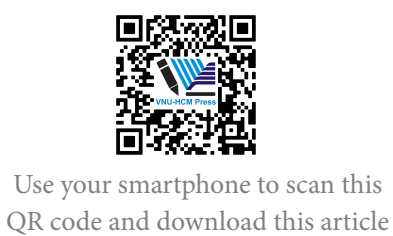

Faculty of Law, University of Economics and Law, VNU-HCM, Vienam

\section{Correspondence}

Nguyen Thi Hong Nhung, Faculty of Law, University of Economics and Law, VNU-HCM, Vienam

Email: nhungnth@uel.edu.vn

History

- Received: 26-4-2021

- Accepted: 29-6-2021

- Published: 15-7-2021

DOI : 10.32508/stdjelm.v5i3.804

\section{Check for updates}

\section{Copyright}

(.) VNU-HCM Press. This is an openaccess article distributed under the terms of the Creative Commons Attribution 4.0 International license.

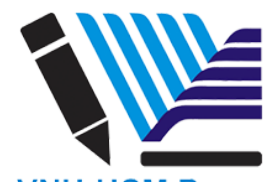

VNU-HCM Press

\begin{abstract}
Applying digital technology in state management activities is a trend that many countries are actively implementing. Experiences from other foreign countries show that digitizing and technologizing judicial activities is an inevitable trend to simplify administrative procedures, maximize the settlement of disputes to ensure legitimate rights of people, and to maintain social order. Vietnam is therefore not out of that trend. However, the application of information technology to the Court's activities in Vietnam has just been initially organized through a number of activities such as online filing, electronic case management..., but for the online trial, the Vietnamese law still does not have a complete legal framework. In the context of Covid-19 epidemy, the employment of E-court becomes even more necessary than ever. Because of social distancing, many activities, including court trial have been postponed. This can cause many inconveniences to the court (to comply with the law on procedural time), and to the parties (who wants to solve their legal issues as quick as possible, so that they can enjoy well their legal rights and interests). However, this model of court needs many conditions to be developed: investment of Government, qualifications of competent persons, people's scientific and technical level... It should be noted that technological measures are just a different implementation method of the procedural provisions, but due to being as the procedural law, these implementation steps should be clearly specified in the law, so as not to be considered a violation of the proceedings. Thus, the contents of law need to be legalized such as applicable conditions, procedures on initiating a lawsuit, on giving announcement to parties... In fact and theory, all kind of civil cases can be judged online as long as the requirements of platform and demand of participating parties are met. And the civil procedure law can add regulations about the online method to some of necessary procedural steps as an additional choice to the parties. The article focuses on recommending the building of a E-Court model in Vietnam in civil proceedings, where this model can be effectively applied due to the civil nature of the case, with the research method of analysis, thesis and comparison with other foreign laws, such as Malaysia, Korea, Australia and Canada.
\end{abstract}

Key words: E-Court, online court, online procedure, electronic case management, digital technology

\section{INTRODUCTION}

Applying digital technology in state management activities is a trend that many countries are actively implementing. E-government and e-court model are two areas with remarkable changes. Experiences from other foreign countries show that digitizing and technologizing judicial activities is an inevitable trend to simplify administrative procedures, maximize the settlement of disputes to ensure legitimate rights of people, and to maintain social order. Vietnam is therefore not out of that trend.

In Vietnam, with the guidelines of the Communist Party and the State on the judicial reform in the industrial revolution 4.0, the judiciary, especially the Court has been promoting information technology in judicial activities to meet the integration requirements of the country's judiciary, in line with the general trend of the world. In particular, in the present time, the implementation of an E-Court is becoming more urgent than ever when Vietnam and the world are facing the Covid-19 epidemic, hindering many judicial activities, affecting the legal rights and interests of people.

The Vietnamese Court also has a project that by 2024, it will implement the E-Court model (also known as "Virtual Court" in English and "Cour virtuelle" in France) ${ }^{1}$.

E-Court is understood that the Court will conduct proceedings through the application of information technology in receiving the petition, documents and evidence, the online trial ${ }^{2}$. So that the litigants do not have to be present in person in the hearing session at Court, but can still participate at home or at work with network connection. This means that E- 
Court and traditional court are not procedurally different. But the difference exists in the way the proceedings are deployed. In E-court, the processes are all done online, instead of face-to-face as traditional way. However, because it relates to the procedure, we also need to have legal recognition of this method in order to implement it effectively and legally.

Civil cases are between private parties, relating to many fields, such as: family and marriage, contract, labour, business... [ ${ }^{3}$, art $\left.26-33\right]$. This kind of case need to be solved as simple and quickly as possible, to ensure social order, citizen rights, rights and interest of individuals and organizations for the purpose of a healthy civil and business environment, to develop country ${ }^{4}$. Therefore, the need to implement Ecourt in civil procedure is necessary in this field, because there are many conveniences that E-court can bring to involved parties and the competent authorities: shorter time, cheaper cost, ... to help to increase the trial rate. According to the Civil Procedure Code of Vietnam, the Court must comply with the law on civil procedure [ ${ }^{3}$, art 3 , art 15], including time for trial [ ${ }^{3}$, art 203], however, many civil cases are late in resolution, which affects not only to legal rights and interests of involved parties, but also to social order ${ }^{5}$. The rule of law therefore cannot be guaranteed.

The article focuses on recommending the building of an E-Court model in Vietnam in civil proceedings, where this model can be effectively applied due to the civil nature of the case.

It can be seen that at present, the application of information technology to the Court's activities in Vietnam has been initially organized through a number of activities such as online filing, electronic case management... but for the online trial, the Vietnamese law still does not have a complete legal framework. Therefore, to be able to build and deploy an E-Court model in Vietnam comprehensively, the study of this model in other countries around the world is very necessary, to compare with the current legal status of E-Court in Vietnam, for the improvement to Vietnamese law on this matter.

\section{EXPERIENCES FROM FOREIGN COUNTRIES}

Currently in the world, a number of countries have been building e-court models such as Malaysia, Korea, Australia, Quebec (Canada) ... Especially, the judicial system in many countries have to stop activities to meet the requirements of social distance caused by the Covid-19 epidemic, making them promote the application of information technology in adjudication activities to ensure normal operation of the judicial system.

In general, at present, the e-court model of countries is focusing on three main aspects: (i) Online filing system; (ii) The case management system; (iii) Electronic Court Room. Studying the E-Court model of countries around the world will bring a lot of valuable experience to Vietnam in the process of building and implementing this model, thereby helping to simplify the proceedings in Court, in order to meet the judicial reform required by the Viet Nam State.

The first is Malaysia, a country in Southeast Asia, very close to Vietnam. The application of the e-court model has helped Malaysia significantly improve the time for the case resolution [ ${ }^{6}$, p.529]]. For the online filing system, it is carried out via an E-filing system. Citizens can create an account to log into the electronic filing portal. After logging in, the petitioner fills in the case information and attaches scanned evidence documents ${ }^{7,8}$. The application procedure is completed after the litigant completes the information declaration and uploads documents and evidence to the system.

After that, the system will switch to payment of court fees. The payment of court fees is divided into two cases: (i) If the litigants initiate a lawsuit through an authorized representative who is lawyers, lawpracticing organizations, the payment can be done via online banking at the option of time of the involved party; (ii) in the case of self-filing a lawsuit without an attorney, the court's public assistance service related to the online filing will assist the involved party in paying court fees $\left[{ }^{9}\right.$, p. 242$],{ }^{7}$. The petition filing system has been in use since 2011 and is encouraged to continue. By the end of 2017, all law practice organizations in Malaysia are required to file lawsuits and court documents online ${ }^{10}$.

After payment is completed, the case information will be updated and stored in the "My Filing" section of the applicant's account. The applicant will be notified of the status of the accepted application on the system ${ }^{7}$. The communication between the court and the litigants and lawyers is conducted through the Community Portal. Information related to the handling of the case and the schedule of the hearing will be notified to the litigants and lawyers through short messages ${ }^{10}$. Judges and court officials will have accounts for the access to the system to receive case files and resolve them in sequence. Particularly, each judge shall have 1 account with access to a personalized data system called "Personalized My Page", where there are data records of the cases which are sorted scientifically and logically. Through the "Case Management System 
(CMS)", the assistant can: (i) check the related document files; (ii) use a planning tool; (iii) check the number of cases to be heard on a particular date; (iv) check the "Queue Management System" for the presence of related parties... If the parties are present, they will be called into the online courtroom ${ }^{10}$. This system helps the court save a lot of time in the implementation of legal proceedings and also helps to reduce procedural errors. At the same time, the system will assist the court in planning "action". Accordingly, it provides timetable of the personnel and judges, helping the court to determine the working schedule, the date of hearing the cases conveniently. The process and results of the case resolution are also updated in this system.

Online trials are conducted through the "Video Conferencing System (VCS)" platform. The VCS system allows participating parties to carry out proceedings from different locations via computer connected to the Internet. During the trial process, this system also allows users to share documents, image files for the resolution of the case $\left[{ }^{6}\right.$, p.529]. In addition, to support the trial, the "Case Recording and Transcribing (CRT)" System is integrated into the online hearing. When using this function, the judge does not have to write the details of the trial, but the electronic device will automatically record the proceedings. This helps the judge save time, focus and observe the proceedings better. Attorneys and prosecutors may obtain a copy of the records from this system for reference purposes only $\left[{ }^{9}\right.$, p.243]. These data are kept for future appeal, if any.

The second is Korea. As a country has been focusing on information technology development, Korea has electronized many stages and procedures for resolving civil cases in court.

The Electronic Case Filing System (ECFS) allows both the plaintiff and the defendant to file a petition; procedural documents; receive notices on cases, judgments, appeals and check the status of the cases, schedules to participate in legal proceedings. To perform operations on the online filing system, plaintiffs and attorneys must use digital signatures. Once the request is submitted, the system will determine the court fees. The plaintiff or agent has to pay the fee by credit card or transfer money from their bank account. After the system accepts the request and lawsuit content, the system will automatically number the case $\left[{ }^{11}\right.$, p.3940].

The system also allows defendants to receive litigation-related notices. As soon as the parties submit additional documents, the parties will also receive an email/text message notification. The parties also have access to online case records at ECFS to promptly check the current state of the proceedings ${ }^{12}$. Each time the case moves to the next step, the system will automatically notify the plaintiffs, defendants and their attorneys via text message and email. By this way, the litigants receive all the updates about their cases without going to the courthouse [ ${ }^{11}$, p.59]. The system helps to reduce time and costs for parties to conduct, participate in proceedings and enhance transparency in the process of resolving the case.

However, unlike Malaysia, Korea has not yet deployed an online hearings session. At the current stage, Korea is only applying computer and communication technology to assist judges and litigants in face-to-face trial session. Accordingly, the courtroom is equipped with computers for the judges, court clerks to access and manage electronic records and related information and for recording the proceedings; computers for parties to proceedings to use evidence in the form of electronic data; a projector and monitor to display images from a computer to view evidence. In addition, the courtroom is equipped with CCTV to monitor and broadcast the trial; microphone and audio recording equipment used to record the proceedings taking place in the courtroom $\left[{ }^{11}\right.$, p.56]. This can be seen as a necessary preparation stage for the Korea to transition to the full E-Court model in the future.

Next is Australia. Online filing is done via the eLodgment system ${ }^{13}$. Individuals, organizations, businesses or law firms must open accounts at the eLodgment system before filing a lawsuit. It takes about 1 working day to verify information and approve the account. This account is also used to access the Austrian courtroom system (eCourtroom). Through eLodgment, the litigants can file lawsuits to the Australian Federal Court and the Federal Circuit Court of Australia to initiate a case. ELodgment also enables the litigant to track the file processing through the "Lodgment History" section ${ }^{14}$. Payment of court fees is also made online through the Credit Accounts For Approved Court Users when the conditions specified in Article 2.16 of the Federal Court Act are met and the Federal Circuit Court Regulation of 2012. Approved users will pay the monthly court fees incurred by court billing through their accounts at eLodgment ${ }^{15}$. From July 2014, the Court has deployed an electronic court file (the Court's electronic court file - ECF). Federal courts have conducted ECF-based adjudication and implemented technology that allows parties, attorneys, and the public to access electronic case files within their mission ${ }^{16}$. Accordingly, there are two technology platforms deployed: Commonwealth 
Courts Portal (CCP) ${ }^{17}$ and the Federal Law Search (FLS ${ }^{17}$. Parties can access the CCP to access case records, decisions, court orders, judgments or schedules of events in the case resolution ${ }^{16}$. The FLS system also supports the public to look up the cases resolved by the Federal Court of Australia and the Federal Circuit Court of Australia. Database is updated, including all cases resolved since January $1,1984^{17}$.

Online courtrooms are equipped with a wide range of equipment and technologies to assist court hearings. Two notable technologies are the Videoconference facilities and eCourtroom systems ${ }^{18}$.

With the Videoconference facilities, courts can connect and video exchange with parties at registered locations in other areas in Australia or even overseas. Instructions for online exchanges are specifically instructed on the court's website, including equipment parameters, application forms, usage fees, ... ${ }^{16}$.

The eCourtroom system is an E-Courtroom used in the management and resolution of some issues before the Federal Court. This system is integrated with the eLodgment system that provides the means for parties to easily send case documents to the court. In addition, the eCase application also assists parties in the exchange of private letters and drafting of the necessary procedural documents. With eCourtroom, courts can conduct an online review of evidence and documents without the need for the parties to participate directly in court. This system also records all the exchanges between the parties with the judge, and synthesizes them into documents that are open to the parties as well as anyone interested, contributing to transparency during the trial process. However, for documents submitted to the court by the parties, only the parties in the case are allowed to approach. Through eCourtroom, the court can proceed to the trial without the direct participation of the parties in the courtroom. However, the parties are bound to conditions ensuring that the parties participating in a trial through the eCourtroom system must also behave as if they were in person in the courtroom ${ }^{16}$.

Finally, in Quebec (Canada), the spread of the Covid-19 epidemic has caused many judicial activities in Quebec to stop working. This is the reason why the online court model is deployed here. Accordingly, the Quebec Ministry of Justice has decided to increase the necessary measures to maintain the operation of the court without having to physically come into contact with each other, including the establishment of the first online trial.

Specifically, the Court Clerk will contact and provide the parties or their attorneys with information and procedures necessary for the proceedings to take place. Government video conferencing systems have been used to ensure the confidentiality of hearings. In other words, an online courtroom is similar to a video conference that lawyers, litigants, witnesses, journalists ... can connect in their office or at home. It means that they may see and hear each other without going directly to the Court, through their computers or phones. This is not only a situational solution to the pandemic, but it is said that if the online trial goes well, this model could be expanded even after the quarantine ends ${ }^{2,19}$.

In a nutshell, among the E-Court models mentioned above, it can be seen that the e-court model of Malaysia and Australia is quite complete, built with many applications to help the parties communicate with each other in a timely manner without going directly to Court. Meanwhile, in Korea, the E-Court model only stops at filing lawsuits, exchanging documents and managing electronic cases. In some other countries such as Quebec (Canada), the building of the E-Court model is deployed from the requirement of practice (Covid-19 epidemic) to ensure continuous operation of the Court, thereby to ensure the people's right to access justice as well as to maintain social order, to help stabilize socio-economic development in the epidemic crisis. However, whether it has been built and implemented completely or just started to implement, it can be seen that the application of technology to the operation of the Court has brought many benefits such as saving effort, cost, time for people, reducing work for the Court... Therefore, building and applying the e-Court model in solving cases is very necessary, not only for the present period (from the influence of the Covid-19 epidemic) but also for the future.

\section{CURRENT VIETNAMESE LAW}

The current industrial revolution 4.0 has a strong impact on all aspects of social life. Therefore, in order to adapt to the requirements of the new situation according to the guidelines of the Communist Party and the Vietnam State, state agencies in general and courts in particular need to increase the application of information technology in their operations. In order to do this, the improvement of the legal system in order to create a legal basis for the application of information technology in the Court's activities is one of the important issues that need to be addressed.

Currently, the Vietnamese civil procedure law has a number of provisions recording the application of information technology in the Court's operations. Specifically, information technology is applied to 
sending and receiving requests and accompanied documents and evidences [ ${ }^{3}$, art 190, art 191, art 285]; the issuance and delivery of procedural document notices, announcement of judgments and decisions... [ ${ }^{3}$, art 173, art 176, art 269, art 315, art 370, art 375].

And to clarify the way people send petitions and documents electronically, the Council of Judges of the Supreme People's Court issued Resolution No. 04/2016/NQ-HDTP guiding the implementation of a number of provisions of the Civil Procedure Code on sending and receiving lawsuit petitions, documents and evidences, delivering and notifying procedural documents.

It can be seen that on the basis of the above provisions, a number of court proceedings have been carried out through electronic means and have initially achieved some positive results in recent years ${ }^{20}$. Specifically, the online submission and receiving of petitions, documents and evidences has been specifically guided on the web portal of the Supreme People's Court ${ }^{21}$. The People's Court has also put use software to manage the list of cases to be heard, record the Court's orders and the results of each case, ... effectively, accurately, saving a lot of time and cost compared to before ${ }^{22}$. That is a necessary stage to to build and complete the ECourt model in Vietnam.

And to further promote the application of information technology to the operation of the Court in particular and of all agencies and organizations in all fields in general, the Communist Party also issued Resolution No. 52-NQ-TW aims to make a number of guidelines and policies for the Fourth Industrial Revolution.

Accordingly, the Communist Party, the Government, socio-political organizations need to take the lead in implementing a strong digital transformation to ensure unity, interconnection and synchronization; in building digital databases for the Government and authorities at all levels, so that all citizens can update necessary information about the operation of the state; in ensuring database collection and management, and Internet-based transactions in state agencies. Besides, the Vietnam Government need to build cadres and public employees to meet the requirements of the Fourth Industrial Revolution; to standardize and clearly delimit functions, tasks and coordination mechanism among state management agencies in digital transformation implementation; to complete administrative processes and procedures in line with digital government operations to minimize direct transactions. Thus, the building of the E-Court model is completely in line with the policies of the Communist Party and the State, thereby contributing to speed up the process of judicial reform and international integration.

Recently, due to the impact of the Covid-19 epidemic, the question of applying information technology to the Court's operations continues to be raised and receives attention not only in Vietnam but also in many countries in the world. In Vietnam, to face with the sluggishness caused by the epidemic, the Supreme People's Court issued Directive No. 02/2020/CT-TA on the prevention and control of the Covid-19 epidemic in the court system. Accordingly, the courts temporarily stop the direct receipt and delivery of lawsuit petitions, documents and evidences at the headquarters of the courts, but through other methods such as via postal service, electronic portal. In case that the time for the lawsuit has expired and it is mandatory to open a court hearing or meeting, it is necessary to intensify the trial and resolve the case by using the online method when technical conditions are met.

After that, the Supreme People's Court continued to issue Official Letter No.127/TANDTC/VP on prevention and control of Covid-19. Accordingly, the Supreme People's Court directs to limit the organization of court hearings which gather over 20 people in one auditorium and requires the arrangement of an online courtroom to ensure a minimum distance between people $\mathrm{e}^{23}$.

Thus, it can be seen that the building of the E-Court in our country has only been made with very initial steps and still quite limited such as online filing, electronic case management basing on the regulations - bylaws. As for online adjudication, although it has begun to be recognized in our country, there is still no complete legal framework to adjust. Therefore, in order to be able to build an online court model in which information technology is applied to the entire procedural process, the amendment of law to complete the legal framework and legalize the online procedures are quite essential. Because, the development of an online court model will create favorable conditions for people to access justice; save money and travel time for the litigants; limit the postponement of the trial for the reason of the litigant's absence due to the distance; avoid unnecessary prolongation of the resolution of the case; and ensure the publicity and transparency of the Court's operations.

In this context of Covid-19 epidemy, the employment of E-court becomes even more necessary than ever. Because of social distancing, many activities, including court trial have been postponed. This can cause many inconveniences to the court (to comply with the law on procedural time), and to the parties (who 
wants to solve their legal issues as quick as possible, so that they can enjoy well their legal rights and interests). However, this model of court needs many conditions to be developed: investment of Government, qualifications of competent persons, people's scientific and technical level... Those questions take lots of money, time and effort. But there is also a bright spot here. According to statistics, the percentage of people using Internet is $70 \%$ (more than 68 million per 97 million people) ${ }^{24}$. This number is believed to increase in a very near future, basing on 4.0 Revolution. Moreover, as mentioned above, judicial reform has been one of the main purposes in the development of country, which is insisted in Resolution of the $13^{\text {th }}$ National Communist Party Congress ${ }^{25}$. These can create an ideal condition to deploy E-court in Vietnam.

\section{CONCLUSION AND RECOMMENDATIONS}

Through learning about the foreign E-Court models mentioned above and current Vietnamese law on civil procedure and policy on E-Court, we think that the following issues need to be completed:

Firstly, it is necessary to invest in building a technology platform to ensure a complete, comprehensive ECourt model: from receiving petitions, exchanging and serving documents, storing and managing information, to online trial rooms... That unified technology must be applicable to all court levels in Viet Nam, with high security level. This is the most important and necessary step in order to implement the E-Court effectively.

Secondly, on the basis of the new technology, it is necessary to legalize the procedures so that procedureconducting persons as well as participants in the proceedings can perform operations on the platform while ensuring the integrity of the procedure. It should be understood that technological measures are just a different implementation method of the procedural provisions, but due to being as the procedural law, these implementation steps should be clearly specified in the law, so as not to be considered a violation of the proceedings. Thus, the contents of law need to be legalized such as applicable conditions, procedures on initiating a lawsuit, on giving announcement to parties... In fact and theory, all kind of civil cases can be judged online as long as the requirements of platform and demand of participating parties are met. And the civil procedure law can add regulations about the online method to some of necessary procedural steps as an additional choice to the parties.
For the beginning time, the implementation of the ECourt model can initially be experimented for a number of cases at the request of the litigants in certain areas such as Hanoi and Ho Chi Minh City, because they are the two cities that can satisfy the technical infrastructure, as well as the high technology usage level of the litigation subjects. After 1 year pilot of E-court, the Government can assess the model relating to positive and negative aspects of E-court, so that the model can be applied on a national scale in future.

Specifically, it is possible to experiment a pilot model of E-Court for business and commercial lawsuits for the first stage, because the parties in this kind of dispute usually have high technological conditions. Moreover, this area needs to be resolved by the Court in a short time, for saving money and other resources to ensure the business efficiency of the parties. And the experimental application of E-Court can be carried out even when there is only one of the parties having the request of E-Court. Accordingly, the requesting party will be entitled to use technology to participate in the entire civil case resolution process, while the other party (if not willing) can still participate directly in the court room in a traditional way, where there are assistive technology tools to broadcast video and sound signals to the other party.

\section{CONFLICT OF INTEREST}

The authors declare that they have no conflicts of interest.

\section{AUTHORS' CONTRIBUTIONS}

Nguyen Thi Hong Nhung writes Introduction and Conclusion. Luu Minh Sang writes Experiences from foreign countries. Huynh Thi Nam Hai writes Current Vietnamese law.

\section{REFERENCES}

1. H.Minh. Cần tham khảo bài học kinh nghiệm để phát triển Tòa án điện tử ở Việt Nam. accessed on 18/7/2020;Available from: https://baophapluat.vn/trong-nuoc/can-tham-khaobai-hoc-kinh-nghiem-de-phat-trien-toa-an-dien-tu-o-vietnam-447203.html.

2. Salles d'audience virtuelles;Available from: https: //courdappelduquebec.ca/actualites/detail/salles-daudiencevirtuelles/.

3. Civil Procedure Code of 2015, Viet Nam;.

4. Nhung NTH. Giáo trình Luật tố tụng dân sự, Publisher of National University Ho Chi Minh City. 2019;.

5. Phan $H$. Cần hạn chế tình trạng chậm xét xử án dân sự. Nhân dân e-Journal. Accessed on 21/5/2021;Available from: https://nhandan.com.vn/thoi-su-phap-luat/canhan-che-tinh-trang-cham-xet-xu- an-dan-su-334594.

6. Dahlan NK. Appear in Court Thru Video Conferencing System: Recommendation for An Islamic Finance Perspective. International Journal of Recent Technology and Engineering (IJRTE). 2019;8(2S). 
7. Omesti. eCourts Malaysia Phase 2, Law Firm Training, Release 1;Available from: http://www.kehakiman.gov.my/sites/default/ files/ManualLatihanBhgn1.pdf.

8. Accessed on 20/05/2020;Available from: https://efs. kehakiman.gov.my/EFSWeb/Content/data/UserGuide/faq_ 20161228.en-GB.pdf.

9. Hassan KH. The E-court system in Malysia. 2011 2nd International Conference on Education and Management Technology. IPEDR vol.13 @ (2011) IACSIT Press. 2011. Singapore;

10. Ghadas ZAA, Ariffin RAM. E-court system in the Civil court system in the Civil and Shaiah courts: Malaysia perspectives. the International Conference on Islamic Civilization and Technology Management. 2019;.

11. Chongthammakun R. Preliminary Study Report on e-Court Development and Implementation: Lessons Learned from Korean e-Court Experience. Preliminary study report. 2014;.

12. Supreme Court of Korea;Available from: https://eng.scourt.go. kr/eng/judiciary/eCourt/eTrials.jsp.

13. Accessed on 20/05/2020;Available from: https://www. elodgment.fedcourt.gov.au/eLodgment/login.aspx?ReturnUrl= \%2felodgment $\% 2$ fdefault.aspx.

14. Federal Court of Australia. eLodgment. Accessed on 20/05/2020;Available from: https://www.fedcourt.gov.au/ online-services/elodgment.

15. Federal Court of Australia. Set-up of Credit Accounts For Approved Court Users. accessed on 20/05/2020;Available from: https://www.fedcourt.gov.au/online-services/elodgment/ information.

16. L B ALLSOP. Technology and the Court Practice Note (GPN-TECH). 2016. Accessed on 20/05/2020;Available from: https://www.fedcourt.gov.au/law-and-practice/practicedocuments/practice-notes/gpn-tech

17. Accessed on 20/05/2020;Available from: https://www. comcourts.gov.au.

18. Accessed on 20/05/2020;Available from: https://www ecourtroom.fedcourt.gov.au/ecourtroom/default.aspx.

19. Salles de cour virtuelles à Québec ;Available from: https://www.lesoleil.com/actualite/justice-et-faitsdivers/des-audiences-virtuelles-en-plus-grand-nombre729711ed9ced7f0b92dc4d682e033736.

20. Lâm $D$. Tòa án online với nhiều tiện lợi. Accessed on 18/7/2020;Available from: https://nld.com.vn/phap-luat/toaan-online-voi-nhieu-tien-loi-20190830145053588.htm.

21. The supreme people's court of The Socialist Republic of Vietnam, Instructions for sending lawsuit petitions, documents and evidences online and register for receiving procedural documents. Accessed on 18/7/2020;Available from: https://www.toaan.gov.vn/webcenter/portal/tatc/vbhuong-dan?dDocName=TAND055163.

22. Management system and case statistics;Available from: https: //qla.toaan.gov.vn.

23. Quang $\mathrm{CH}$. Tránh gián đoạn do Covid-19, cơ chế phân xử trực tuyến ra sao? Accessed on 18/7/2020;Available from: https://www.viac.vn/tin-tuc-su-kien/tranh-gian-doando-covid19-co-che-phan-xu-truc-tuyen-ra-sao-n875.html.

24. Vnetwork. Thống kê Internet Việt Nam 2020;Available from: https://vnetwork.vn/news/thong-ke-internet-viet-nam-2020.

25. Tuoitre online;Available from: https://tuoitre.vn/toan-vannghi- quyet-dai-hoi-dai-bieu-toan- quoc-lan-thu-xiii-cuadang-20210226101510976.htm. 


\title{
Tòa án điện tử trong giải quyết vụ việc dân sự - Kinh nghiệm nước ngoài và đề xuất cho Việt Nam
}

\author{
Nguyễn Thị Hồng Nhung ${ }^{*}$, Huỳnh Thị Nam Hải, Lưu Minh Sang
}

Khoa Luật, Trường ĐH Kinh tế - Luật, ĐHQG-HCM, Việt Nam

Liên hệ

Nguyễn Thị Hồng Nhung, Khoa Luật,

Trường ĐH Kinh tế - Luật, ĐHQG-HCM, Việt

Nam

Email: nhungnth@uel.edu.vn

Lịch sử

- Ngày nhận: 26-4-2021

- Ngày chấp nhận: 29-6-2021

- Ngày đăng: 15-7-2021

DOI : 10.32508/stdjelm.v5i3.804

\section{Check for updates}

\section{Bản quyền}

๑ ĐHQG Tp.HCM. Đây là bài báo công bố mở được phát hành theo các điều khoản của the Creative Commons Attribution 4.0 International license.

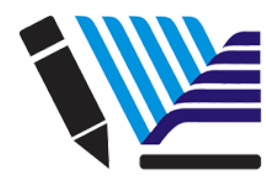

VNU-HCM Press

\section{TÓM TẮT}

Ứng dụng công nghệ số trong hoạt động quản lý nhà nước đang là xu hướng được nhiều quốc gia tích cực triển khai. Kinh nghiệm của các nước trên thế giới cho thấy công nghệ số hóa các hoạt động tư pháp là xu thế tất yếu nhằm đơn giản hóa thủ tục hành chính, giải quyết kịp thời các tranh chấp, bảo đảm quyền lợi chính đáng của người dân, góp phần giữ gìn trật tự xã hội. Việt Nam vì thế cũng không nằm ngoài xu hướng đó. Tuy nhiên, việc ứng dụng công nghệ thông tin vào hoạt động của Tòa án ở Việt Nam chỉ mới bước đầu được thực hiện thông qua một số hoạt động nhu nộp hồ sơ trực tuyến, quản lý hồ sơ điện tử...., còn đới với hoạt động xét xử trực tuyến thì pháp luật Việt Nam vẫn chưa có quy định pháp lý cụ thể. Trong bối cảnh dịch bệnh Covid-19, việc sử dụng tòa án điện tử càng trở nên cần thiết hơn bao giờ hết. Do giãn cách xã hội, nhiêu hoạt động, bao gồm các phiên tòa xét xử cũng phải bị hoãn lại. Điều này có thể gây ra nhiều bất cập cho hoạt động Tòa án (tuân theo quy định của pháp luật về thời gian tố tụng), và cho các bên (muốn giải quyết các vấn để pháp lý của mình càng nhanh càng tốt, được hưởng kịp thời các quyê̂n và lợi ích hợp pháp của mình). Tuy nhiên, mô hình tòa án này lại cần nhiều điều kiện để phát triển: đầu tu của Chính phủ, trình độ của người tiến hành tố tụng, trình độ khoa học kỹ thuật của người dân... Cần lưuý rằng, biện pháp công nghệ chỉ là một phương thức thực hiện khác của quá trình tố tụng, nhưng do là luật hình thức nên các bước thực hiện này cũng cần được quy định minh thị trong luật, để không bị coi là vi phạm thủ tục tố tụng. Vi vậy, các nội dung của tòa án điện tử cần phải được luật hóa như điều kiện áp dụng, thủ tục khởi kiện, thông báo cấp tống đạt văn bản tố tụng... Trên thực tế và lý thuyết, mọi loại vụ việc dân sự đều có thể áp dụng tòa án trực tuyến miễn là đảm bảo yêu cầu về kỹ thuật và theo yêu cầu của các bên đương sự. Và pháp luật tố tụng dân sự có thể bổ sung quy định về phương thức trực tuyến vào một số bước tố tụng cần thiết như một sự lựa chọn bổ sung cho các đương sự bên canh phương thức tố tung truyên thống. Bài báo tầp trung vào việc khuyến nghị xây dựng mô hình tòa án điện tử tại Việt Nam, theo đó mô hình này có thể được áp dụng hiệu quả trong tố tụng dân sự, với phương pháp nghiên cứu phân tích, tổng hợp và so sánh với luật nước ngoài như Malaysia, Hàn Quốc, Úc và Canada.

Từ khoá: tòa án điện tử, tòa án trực tuyến, thủ tục trực tuyến, hệ thống quản lý vụ án điện tử, kỹ thuật số
Trích dẫn bài báo này: Nhung N T H, Hải H T N, Sang L M. Tòa án điện tử trong giải quyết vụ việc dân sự - Kinh nghiệm nước ngoài và đề xuất cho Việt Nam. Sci. Tech. Dev. J. - Eco. Law Manag.; 5(3):1733-1740. 